\title{
"This School Saved my Life": \\ How one Innovative Charter High School Succeeds with Dropout Recovery
}

\author{
Letitia Basford $^{\mathbf{1}}$ and Joe Lewis ${ }^{2}$ \\ ${ }^{1}$ Hamline University, United States of America \\ ${ }^{2}$ Hamline University, United States of America
}

\begin{abstract}
In this article, the authors examine how one charter high school in the U.S. is successfully serving students who have not succeeded in the traditional school system and are therefore at risk of dropping out or being caught in the school-to-prison pipeline. The school-to-to-prison pipeline is a theoretical construct that explains how disproportionate disciplinary and exclusionary punishment of students of color ultimately pushes youth out of mainstream schools and into the criminal justice system (Basford \& Lewis, 2018; Heitzig, 2016; Fuentes, 2011; Morris, 2016). Most research on the school-to-prison pipeline calls for preventive measures to be implemented in schools, such as employing culturally responsive teaching practices and correcting biased disciplinary and zero tolerance practices. However, little has been studied on how schools can work successfully with youth who have already experienced the school-to-to-prison pipeline-youth who have previously been pushed out of school, experienced juvenile detention, and/or mandated prison sentences. The authors respond to this void in the literature by describing the successful efforts of one school. The school is successful because of five key qualities: a casual, family-like atmosphere; a commitment to remaining small; creative responses to erratic attendance; extreme patience and flexibility in the classroom; and innovative, trade-focused programs. The authors examine each of these qualities in detail, and the central challenges the school faces as it seeks to serve students effectively. Finally, the paper describes an overarching model for serving adolescents who are at risk of dropping out- a philosophy and practice of pedagogical and institutional plasticity.
\end{abstract}

Keywords: alternative ways of teaching; adverse childhood experiences (ACEs); at-risk youth; charter schools; teaching to restless \& disruptive pupils 


\section{Introduction}

The Westside Recreation Center (a pseudonym), situated in a working-class residential neighborhood of this large upper-Midwest city, is a modest facility. There is a sports field, a playground, and community garden space. The aging, brown-brick building houses a small gym, offices, and a handful of meeting rooms. Still, it is a clean and inviting space. A friendly guard (more of a greeter) checks in visitors with a smile. Young men and women shoot hoops in the gym. Depending on the time of day, you might see young kids participating in an early childhood program or adults using a meeting space. What you are almost certain to see is a group of 17-to21-year-olds and their teachers, since this small recreation center is also home to one of the country's first experiments in charter school education. Little Metro High School (a pseudonym) has called the Westside Rec Center home since the late 1990s, and since that time, it has stuck faithfully to its initial mission of serving young adults who have not succeeded in the traditional system. "Our number one preference is kids who have dropped out or are at risk of dropping out," says the school director and one of its founders, who has been at the school for 24 years. "There wouldn't be a purpose for our school if the kids were succeeding somewhere else," she emphasizes.

This study focuses on schools using non-traditional approaches to reach students who have not succeeded in the traditional system. Little Metro first appeared on our radar when we visited it as part of a guided clinical experience for students in our teacher education program. We were impressed with the staff's commitment to and skill at serving its students. The family-like atmosphere and the flexible pedagogical approaches appeared to work well. Interviewing leaders of the school, we discovered that it graduates an impressive 60-70 students a year, averaging about $85 \%$ of its senior students, many of whom would have otherwise dropped out. In addition to meeting state graduation standards, these students develop individualized plans for post-secondary success. Little Metro has purposely remained small and inconspicuous, but in education circles it has built a strong reputation for serving at risk teens.

The initial idea for Little Metro came about when the founders saw a disturbing number of teenagers giving up on school. The director (who still prefers the title "teacher") explains, "We saw a lot of kids quitting and a pretty significant group who were not happy. So we literally followed them out the door and asked, 'Why are you leaving?' They told us, 'Nobody knows me.' They felt uncomfortable in a crowd." What followed was a pilot program based on those basic ideas - a small school where people really knew each other, and a focus on kids who were not happy in the large, traditional system. The plan emerged just as the state's charter school legislation was coming out, so the founders opted for a charter school approach (very controversial at the time), because it provided the best way for them to maintain local control over the school's program. The director explains:

Mary: ${ }^{1}$ We started with the kids who were walking out of other schools and just encouraged them to give this new program a try. Initially, we thought that we wouldn't be around for very long. I mean, look how fun this is. It keeps kids in and it really creates a family atmosphere for students and teachers. We figured that everyone would start doing

\footnotetext{
${ }^{1}$ All participants have been given pseudonyms.
} 
this, at least for those kids who were leaving the bigger schools. But we're still here. Today, we don't do any recruiting. Kids find us now and we always have a waiting list. (White female school director and teacher)

Demographically, the school has consistently reflected the makeup of the surrounding neighborhood, which has changed some over the years. The initial group was mainly Latino and African-American students. Today, Hmong Americans make up the biggest population, followed by Latino students, African-American students, and smaller groups of White and Native students. Unlike many city charters which draw from a wider area, Little Metro has always drawn from the west side. Students tend to be older, in the 17-21 range, which means that they have often missed the "graduate on time" target set by the state. School administrators told us that over 95\% qualify for free and reduced lunch and close to half have been diagnosed with special needs. Before finding Little Metro, these students were at high risk for dropping out and being caught in the school-toprison pipeline, although the school director is quick to point out that these students were not "destined" for prison; they simply required a school that met their needs.

What brings these specific students to Little Metro? The main reason appears to be linked to that initial vision. The large, traditional schools were too cold and put up too many roadblocks. Students were looking for something smaller and more personable. Teachers explain further:

Emily: The thing that sort of ties all of the students together is that a traditional high school was not working for them - the big class sizes, the requirement of having to be there every day. (White female art teacher)

Leah: A common student might be one that was at a big high school and they weren't successful. Maybe because of attendance or life changes, like having kids or needing to work, maybe a family health problem or homelessness. Some students have been in and out of juvenile detention. (White female math teacher)

Maya: Our students are amazing kids, but just hearing some of their experiences, you also know that many of them have been exposed to trauma. (White female social studies teacher)

Another common characteristic of students at Little Metro is that many have faced adverse childhood experiences (ACES), at home, on the street, or in previous schools, so they benefit especially from a small community that is able to surround them with support. They also need teachers who are empathetic, skilled at building relationships, and knowledgeable about trauma informed practices.

\section{Theoretical Framework}


 \\ CLNAEDUCATIIN \\ 27-29 March, 2020 Oxford, United Kingdom}

In this next section, we provide a theoretical grounding for the study by examining recent literature on the school-to-prison pipeline, adverse childhood experiences (ACES), trauma informed practices, and dropout prevention.

Michelle Alexander's (2012) seminal work The New Jim Crow has highlighted a steady increase in U.S. incarceration rates, which have grown from around 300,000 in the 1970's to well over 2 million today. Alexander and Bryan Stevenson (2013) have documented a dramatic increase in drug-related arrests and convictions that have targeted low-income communities of color almost exclusively. In the same way that poor men of color are targeted for arrest and incarceration on a societal level, boys and young men of color are in greater danger of experiencing disproportionate discipline and exclusionary or repressive punishment in schools (Noguera, 2008; Heitzig, 2009). Young men of color often get labeled as "problem kids" or "bad boys" early on in school; they get pushed out of mainstream classrooms, experience suspension and expulsion at much higher rates, and often wind up in the school-to-prison pipeline (Lewis \& Basford, 2014; Christle, Jolivette, \& Nelson, 2005; Nocella, Parmar, \& Stovall, 2013). Though it affects males at higher rates, the phenomenon is not exclusive to young men; young women of color, especially low-income students, are also at higher risk for experiencing the school-to prison-pipeline (Morris, 2018; Crenshaw, Ocen, \& Nanda, 2015). Ironically, we dole out the most severe discipline to those kids who are most in need of support. They tend to come from single-parent homes and live in poverty; some live in foster homes; many are homeless. Instead of supporting these youth, mainstream schools have used "zero-tolerance" as an excuse to give up on them.

Meanwhile, a growing body of evidence has pointed to the impact of prolonged stress and trauma on the lives of young people (Sciaraffa, Zeanah, \& Zeanah, 2017; Bornstein, 2013; Ganzel \& Morris, 2011). This research suggests that standard responses to negative behavior in schools (namely, the zero-tolerance approach of publicly calling out misbehavior and doling out increasing levels of punishment) is, in fact, part of the problem. In our efforts to "hold kids accountable," we often punish them for behaviors that are out of their control and may even be natural responses to childhood trauma or high degrees of stress. Adverse childhood experiences (ACEs) such as physical or emotional abuse, domestic violence, drug or alcohol addiction in the home, or having a household member in prison can lead to negative health outcomes and negative performance in school (Stevens, 2018).

Research on ACEs suggests that schools and teachers can play an important role in easing student anxiety and depression, improving their coping skills and self-confidence, and helping them build a sense of self-worth (Stopa, Barrett, \& Golingi, 2010; Blitz \& Saastamoinen, 2016). The negative effects of ACES can be counteracted with "resilience promoting environments" that center on "protective caregiving relationships," both at home and in school (Woods-Jaeger, Cho, Sexton, Slagel, \& Goggin, 2018, p. 1). This has led to the creation of trauma sensitive schools, where staff are trained in how to help traumatized children learn. To date, this work has centered on early childhood and elementary level learning (Sciaraffa et al., 2017), though ACEs can have a "strong and cumulative impact" on adolescents and adults (Minnesota Department of Health, 2011). There is a dearth of research on what schools can be doing to serve adolescent students with ACEs. 


\section{SICNAEDULATION}

27-29 March, 2020 Oxford, United Kingdom

Trauma informed teaching practices focus on how teachers relate to students who have experienced exclusion and failure in conventional school settings. Not only do teachers seek to understand how previous experiences might influence current learning habits, they also intentionally prioritize building relationships of trust and safety as an essential first step in helping students find pathways to success (Morgan, Pendergast, Brown, \& Heck, 2015). A mutually respectful and caring relationship forms the basis for student's re-engaging with school and making progress toward graduation (Morgan et al., 2015).

Current research on dropout prevention reinforces these same core ideas. Among the most common reasons for dropping out: stressful life events (another way to describe ACES); frequent suspensions and expulsions (or disproportionate discipline); poor attendance; and teachers being perceived as not caring about students (Freeman, 2013). Wilkins and Bost (2015) emphasize the following interventions as most effective at reducing dropout rates: providing adult advocates for students; personalizing the learning environment; and individualizing instruction. In one exploratory case study (Iachini, Buettner, Anderson-Butcher, \& Reno, 2013), student participants consistently expressed their desire for a smaller school size, schedule flexibility, and an individualized approach to learning -- traits that Little Metro's director would describe as "common sense," since they fulfill the basic human needs of being recognized as an individual and belonging to a supportive community.

In this study, we examine how Little Metro serves young adults who are in danger of dropping out and potentially experiencing the school-to-prison pipeline. Teachers do this, in large part, through the use of trauma informed practices that attend directly to the impact of ACEs on adolescent learning.

\section{Methods, Data Collection, and Analysis}

Our study seeks responses to the following research questions: How do staff and students describe their experiences at Little Metro and how do those experiences differ from traditional settings? What specific school practices appear to be successful for students at Little Metro? What challenges does the school face? What aspects of the school's approach might be applicable to other settings?

We designed an interpretive ethnographic study (Merriam, 1998) to better understand how Little Metro keeps students motivated and engaged to stay in school and graduate. The study draws on interview data and observations. Primary participants were teachers ( $n=11$ out of 15 total), including the school director, who also teaches. Teacher participants were selected based on the director's recommendation, our observations, and interest in the study. Secondary participants $(\mathrm{n}=10)$ were students. All student participants had attended different K-12 schools before coming to Little Metro. They were selected based on availability and interest in the study. We conducted eight open-ended, 1-2 hour individual interviews with school staff and two focus group interviews with students. All interviews were audio-taped and transcribed for analysis. We also visited the school over 20 times, observing both classroom and school-wide activities to broadly understand the nature of the school experience.

Using interview transcripts and notes from observations, we used an interdisciplinary approach for ongoing data analysis. We constructed categories from the interview data according 


\section{LNAEDULATIION

to Merriam's (1998, p. 181) guidelines. We then compared categories, named them, and came up with a classification scheme. Initial findings were shared with study participants to verify their dependability.

\section{Results: Key Qualities of Little Metro High School}

In what follows, we describe five key qualities of Little Metro High School that we believe lead to success with the students. These include: 1. A casual, family-like atmosphere; 2. Commitment to a small, close-knit community; 3. Creative responses to absenteeism; 4. Extreme patience and flexibility in the classroom; 5 . Innovative, trade-focused programs.

\section{Quality \#1: A casual, family-like atmosphere}

Lunch at a Little Metro is a communal event. With rare exceptions, everyone in the building gathers in a central location to sit at small, circular tables and share a homemade meal, served family-style. The school chef, a former student known for his skill at making pizza and maintaining a fresh salad bar, tries to keep the menu healthy and local. When we joined in, the atmosphere reminded us of summer camp. Every table had at least one teacher and 4 or 5 students chatting quietly. People lingered after they had finished eating, bussed tables together and swept the floors, then wandered off to afternoon classes without any formal reminder.

Contrast this with a large traditional high school and you'll get a sense of what makes the atmosphere at Little Metro unique. In a large school cafeteria, students wait in long lines to get institutionalized food. They are expected to eat quickly and move along. Hired staff, whose primary function is crowd control, stand in strategic locations around the room. And there just tends to be a general feeling of anxiety in the air. This is a large room filled with many teenage bodies, a space where something could easily go wrong (an argument, a food fight, harassment, violence). It is precisely the type of atmosphere that Little Metro students are seeking to escape and Little Metro teachers are hoping to counteract with a radically casual and personalized approach to school. Teachers explain:

Leah: We listen to each other and respect where people come from and what they have to say. A lot of our students came from schools where they did not feel connected, so we really try to have a warm, friendly atmosphere. We eat together. We joke together. (White female math teacher)

Oliver: We try to get to know our students on a personal level. We all use first names. We each have 10-15 advisees that we are personally in charge of, so we'll work on their schedules and get to know them really well. That helps create a warm environment. (White male science teacher)

Anna: The environment here is very accepting and respectful of difference. It's a family. We care about each other and respect each other. If someone decides not to go along with that, we don't just kick them out. We talk to them about it and try to work it out. (White female art teacher)

As Anna's comment suggests, the school also uses a highly individualized approach to discipline. "We spent our first year working with students to come up with a set of rules," explains the school 
 \\ ILNAEDULATION \\ 27-29 March, 2020 \\ Oxford, United Kingdom}

director. "Eventually, we boiled it down to two words: respect and communication. That has been our 'rule book' ever since. If someone feels disrespected, we talk about it." Discipline is handled on a case-by-case basis, with those involved sitting down to talk through the situation and arrive at a logical solution together, an informal program of restorative justice. Teachers try to frame everything as a choice that students are free to make, including the very basic decision of whether or not to come to school. They are also quick to point out that discipline isn't much of an issue at the school.

Leah: There just aren't a lot of power struggles. We don't have situations where the teacher says, 'Do this or else.' It's more like, 'We're here to support each other, and if you're making certain choices, then you may not get the outcome you're looking for.' A lot of our students, if they're confronted with someone emphasizing power, then it's easy for them to get angry, so we don't do that here. (White female math teacher)

Emily: Honestly, we have very few discipline challenges. We're kind of a big family.

People are proud to be here, so they tend not to act out. (White female art teacher)

The relaxed atmosphere appears to have greatly reduced the number of discipline challenges. The few incidents that do arise are comparatively easy to address, since students are choosing to be there and are welcome to leave at any time (in the same way that no one gets kicked out of Little Metro, no one is ever forced to stay). Meanwhile, senior students play an important role in helping to acclimate their newer peers. "It's sort of fun to hear the more experienced students say to the newer ones, 'We don't do that here' or 'That's not what we're about," says the school director. "When the new kids are testing boundaries, the experienced ones really help us to establish that atmosphere of respect." Even students who might consider themselves "enemies" outside of school, because of gang or neighborhood affiliation, tend to leave their disagreements at the door. One teacher explains:

Steve: We have young people here from different groups that don't get along outside of school. At night, they're on opposite sides of the street. But when they're here at school or on the work site, they're supporting each other, laughing, shaking hands. (White male, Youthbuild leader)

A student summarizes how Little Metro changed her life:

Che: At my old school, I got into fights and got kicked out. I stopped caring about my education. I was ditching school. No one cared if I graduated. When I came here, the teachers were so energetic and caring. It made me feel wanted, part of a family. Honestly, this school saved my life. (Hmong-American female, senior)

That family-like atmosphere is possible, in part, because the school is committed to remaining small.

\section{Quality \#2: Commitment to a small, close-knit community}

Teachers consistently emphasized the school's small size as a key component of its identity and success. Class sizes are capped at 12 and are often as small as 5 to 10. Co-taught classes (which are common) are capped at 20, though they tend to run in the 10 to 15 range. The small class size makes it possible for teachers to build close relationships with students and individualize their instruction and curriculum. The total population of the school is also kept low. "We've made a 
conscious decision to max out at 115," says the school director. "That was student designed. When we've gone above that number in the past, students told us, 'No, it doesn't feel the same." The commitment to stay small comes at a price, since the school depends on the state's per-pupil funding as its primary source of income. Facility costs are kept as low as possible and extracurricular opportunities are limited, but both teachers and students see many benefits:

Anna: Our small size allows for much more individualized learning. It's a real luxury. I always have a project focus to my classes. With a small class, let's say 8 students, they can each be doing different projects and it works well. (White female, art teacher)

James: In a traditional setting, you have $30+$ kids in a classroom and they've been in that setting for 8-10 years. Their mind set is so different. They've gotten used to being ignored. When they come here, some students have a hard time adjusting. But once they do, they realize this is a good place. We're not trying to be your problem. We're trying to be your solution. We're trying to be there with you. (Hmong-American math teacher)

Leah: Our biggest advantage is that we're very small and that just leads to all kinds of possibilities. We're able to ask: What does this one person need? What's the best schedule for this student? Which teachers are they going to work best with? And then we can adjust in response to that need. (White female math teacher)

The students we spoke to and interacted with agreed that small size and personal attention is a major part of Little Metro's appeal. "At my old school, I felt like I wasn't getting the help I needed," says one student (an African-American male). "With so many kids, teachers can't help you. Here they have small classes and really help you."

Above, we've emphasized some of the positive qualities of Little Metro. One major challenge the school faces is absenteeism. Teachers try to face this challenge with creativity and patience.

\section{Quality \#3: Creative responses to erratic attendance and absenteeism}

Teachers at Little Metro consistently identify erratic attendance and absenteeism as their primary challenge. For a variety of reasons, students are often unable or unwilling to attend class every day. In more traditional settings, this creates a major barrier to success, since students are dropped from classes or expelled because of poor attendance. The following teacher comments are representative of what we heard about absenteeism:

Leah: A lot of students come in with serious truancy issues, for various reasons: they may have a kid; they may be homeless; they may have a job that their family is really depending on. Or maybe they just don't have any excitement about going to school and they have a history of not being interested. (White female math teacher)

Cheryl: We have a lot of kids who have challenges in their lives besides school. Also, some students have had some terrible experiences in education. Sometimes they've become distrustful of teachers and the system. (Hmong-American female social studies teacher) Instead of addressing absenteeism with punishment, Little Metro has designed a unique system that makes it possible for students to earn a diploma even when their attendance is spotty. As students realize that graduation is possible, attendance tends to improve. The school tries to focus 


\section{SICNAEDULATION

on incentives to attend, rather than penalties for being absent. Below, we outline some of their creative responses to the challenge of erratic attendance.

Capstones, not credits: Traditional schools use credits to represent progress toward graduation, and seat time (i.e., attendance) is often necessary to earn those credits. In contrast, Little Metro uses a system of capstones based on student competencies. Instead of sitting in class and completing a series of worksheets and tests over a semester, students must demonstrate what they know and can do, often through individualized projects. "In our system," explains an advisor, "it's not a matter of seat time. It's about the quality of the project. When they've completed it and have shown us that they have that competency, then they've earned the capstone. One capstone might take a week or a year, depending on the student." Ideally, students come to realize over time that they can complete more capstones if they attend regularly and make progress on their various projects.

To graduate, students must complete 26 capstones, most of them rooted in state graduation standards (in math, communication, science, etc.). As part of the graduation process, they must also demonstrate that they have explored post-secondary options - whether educational, careerfocused, or both - and develop a plan-of-action. The school focuses on helping each student prepare for his or her specific future, which may involve college, technical school, or a job.

Short sessions, not semesters: Instead of traditional semesters, Little Metro schedules ten shorter sessions over the course of the year, ranging from 3 to 6 weeks long. Shorter sessions make it possible for students to dip in and out of school, depending on their needs and preferences, while still making progress toward graduation. Teachers explain:

Leah: For a lot of our students, the stamina required for a nine-month class is challenging, so we take it in smaller chunks. Students feel like they've made some progress and can start fresh with something new six weeks later. (White female math teacher)

Emily: As long as they are here and getting the work done, students can make good progress in each session. If a student only makes it to half of a session, they probably won't complete that capstone, but they can keep working on it the next session. (White female art teacher)

Rather than using a zero-sum game, where students fail and must begin again, there is a sense of continual progress. If a student reaches the end of a session and hasn't finished a capstone, s/he can continue working independently or sign up for the same class again (without having to start over completely).

Use of technology: More recently, teachers have begun to use technologies such as Google classroom to keep students connected, even when they miss class. A social studies teacher explains:

Cheryl: We shifted to Google classroom and one-to-one technology and that has felt like a real game changer. When I have an in-class activity, I'm trying to make it engaging and I'm adjusting to meet everyone's needs. But if you're not in class, then you miss out. So I also try to have a pretty straightforward assignment on google classroom that matches whatever we did in class. (Hmong-American female social studies teacher) 
Teachers admit that they'd prefer to see students in person and actively participating, and they still struggle with the negative impacts of absenteeism, but technologies like Google classroom have helped some students stay connected, where they might otherwise lose touch completely.

Sought after trade-programs linked to attendance: Below, we describe Little Metro's innovative trade programs, which combine opportunities to earn capstones with skill development in a specific trade. These programs also provide a stipend, making it possible for students to support their families and/or save money as they attend school. Because the trade programs are popular, the school has made a conscious decision to link participation to attendance. Before a student can begin a trade program and during the program itself, s/he must demonstrate an ability to attend class regularly. As one might predict, attendance improves dramatically for students in these programs. The leader of the Youthbuild program explains:

Steve: We have the best attendance, because the kids really enjoy the hands-on, physical work. The stipend is also a major incentive. They get $\$ 10$ an hour. We tie their stipends to attendance. If you're late to the site or late to class, there's a $\$ 5$ tardy fee. If you skip a class, then you lose your stipend for the day...They learn pretty quickly to have good attendance. And even when they do skip a class, they still want to be here at the site to work. (White male Youth Build leader)

Little Metro is looking continually for ways to motivate students to improve attendance and move toward graduation. While such creative approaches help, absenteeism continues to be a challenge. Dealing with it requires not only creative responses, but extreme patience and flexibility on the part of teachers.

\section{Quality \#4: Extreme patience and flexibility in the classroom}

Teachers at Little Metro are highly committed to building relationships with their students as an essential first step in guiding them toward success. Every teacher we spoke to talked about the importance of those relationships. We were impressed with their dedication to this goal and noted that a great deal of patience was required for it to work. During one interview, for example, a teacher told us at the outset:

Maya: I have a student right now who I haven't seen for a while and I'm not sure what's going on with him. I've been emailing and calling: 'Come in, come in. We miss you. How can we get you plugged back in?' If I see that student now, I'm going to have to bolt just to get some face time with him. It can be really hard when you feel personally invested in a student's success and you just don't know what's going on. (White female social studies teacher)

That personal investment in each student, and the uncertainty that can go with it, is a central part of the job at Little Metro, requiring emotional endurance and a willingness to accept unknowns. But over time, such patience and persistence can pay off, as one teacher explains:

Anna: Sometimes you think it's not working, that nothing's happening. You want to give up, because it feels like they have. But if you just stick with them and sort of wait them out, a light turns on and they get to work. Most of them want to graduate, they want to accomplish something. That diploma gives them a sense of accomplishment and they know it's a stepping stone to something better. (White female art teacher) 
Whether they've been formally trained in trauma informed practices or not, teachers at Little Metro understand that a respectful and caring teacher-student relationship forms the basis for student's re-engaging with school and making progress (Morgan et al., 2015). For some students, developing that sense of belonging must take precedence over academic progress, as another teacher explains:

Cheryl: Today we were eating lunch with a student who's gone through many different schools and had a lot of challenging experiences. He has finally landed here and it feels better for him. He wants to participate. He feels included and engaged. For him right now, that's more important than being academically successful. We'll eventually get to the academics. Right now, he just needs to belong. (Hmong-American female social studies teacher)

Building on those individual relationships with students, teachers at Little Metro also seek to individualize their teaching, practicing an extreme form of pedagogical flexibility. This can be difficult for teachers accustomed to more traditional settings. "You have to be willing to set aside scope and sequence and prioritize other things," explains a curriculum specialist. "You might be working with 6 kids in the same class at very different places in their skill level and prior knowledge. You'll also have kids coming in every day that have missed previous material." Teaching at Little Metro requires at least two forms of flexibility: differentiation of curriculum and pedagogy based on student ability and interest; and responding to fluctuating groups of students, due to inconsistent attendance. "You really can't do a traditional lesson plan," explains another teacher. "I tend to plan my sessions as a 'to do' list. When students come in, I'm trying to move each one forward on their list." And while every teacher we spoke to emphasized the importance of flexibility and creativity, they each had different methods of putting it into action, depending on their area of teaching and personal preferences. Below, teachers describe some of the approaches they use in different academic areas.

Math: I always use a pre and a post assessment for my classes, to get a sense of progress. But the curriculum itself tends to be student-by-student, since they're all at different levels. It's not like Algebra 2 and they all have to meet the same standards. It's much more individualized - this person is working on this skill and the next student is doing something different. I use themes to tie it together. For example, I teach a class called Math Games, where we do a lot of probability and statistics. The theme is how to use mathematical strategy effectively, so that's infused throughout the course. Within the theme, I'm able to differentiate based on student ability, and nudge each of them forward in their understanding of math. (White female)

Social Studies Teacher: I want them doing work that they find engaging and important. I use a lot of individual projects. For a genocide unit, we did a week or so of group stuff, but then I had each of them choose one thing to focus on for an individual project. This ends up being the best way to work with students where they're at, especially with such a range of academic levels. (White female)

Many courses at City Academy are co-taught, making it possible for students to think across disciplines and work on more than one capstone in the same course. One example is a course called "A Closer Look," which combines science and art. Drawing is used as a strategy to help students observe nature closely and make inferences about what they are observing. Frequent field 


\section{LNAEDULATIION \\ 27-29 March, 2020 Oxford, United Kingdom}

trips are possible because of the small class size and access to a school van, so they can easily go to the zoo or a city park or forest. Another co-taught class is "Freakonomics," which uses the work of Levitt and Dubner (2005) to examine statistics that challenge conventional wisdom on a host of social topics. This course is co-taught by a social studies and math teacher, so it addresses capstones in both areas. Co-teaching not only allows for curricular creativity, it also encourages teachers to process how students are doing with each other and cooperate in their approaches to student support.

Discussing the importance of curricular flexibility, teachers simultaneously praise the freedom they have and admit to the challenge of the work:

Cheryl: It's very empowering as a teacher to have the autonomy to design and teach classes that really speak to my students. We do have a curriculum committee, but if I can show them that my idea will be engaging, that it's going to connect with students, then the committee trusts me. We trust each other. (Hmong-American female, social studies teacher)

Mary: Teachers here get very small class sizes, but they also have to get good at developing their own curriculum for each class and each student. You have to think of each student as a work of art. It's highly individualized instruction, but in a group setting, so students get that social interaction piece. Doing it well is difficult. (White female school director and teacher)

In addition to small class sizes and individualized instruction, students at Little Metro are also drawn to the hands-on, career-focused trade programs.

\section{Quality \#5: Innovative, trade-focused programs}

We first met Steve, the Youth Build leader, on a sunny spring day at the work site, a residential city lot about three blocks from Little Metro. The site project will be a single-family home managed by a community housing organization that supports low income families. When we arrived, a crew of seven young men and women were getting tools and other materials ready for the morning's work. Steve took about ten minutes to get them started on their project, then joined us for an interview. The crew worked diligently as we talked. At no time did Steve need to stop and redirect them. "I'm really focused on team building out here," he explains. "I've been working with kids for 23 years as a hockey coach, and I sort of approach it the same way here." He continues:

Steve: Teams gel when people are working together and mentoring each other. That's what it feels like here. These kids are seeing success and they're feeling good about what we're doing. This is a serious work site. There's no swearing out here. There's no horse play. We have to be safe. And these kids police each other, because we're succeeding together and accomplishing things as a team. (White male Youth Build leader)

He talks further about helping his team develop their soft skills for the trade industries, like being on time, speaking professionally to the crew manager, working hard, and knowing how to manage time. He points out that there are good jobs available in the trades (many contractors cannot fill their crew rosters). His crew works the Youth Build site for a $\$ 10$ stipend, as they build their skills and earn a diploma. If they finish that diploma with a good recommendation from Steve, 


\section{SICNAEDULATION

they have the potential to double or triple that salary after a year of apprenticeship and success on the job. Steve makes a strong argument for a return to trades education in general, pointing out that you don't need a four year degree to make a good living and that not everyone is cut out for classroom learning. "It doesn't mean that you're dumb or lazy," he tells his crews. "It means that you learn best by doing." Steve is a grassroots advocate for experiential, hands-on learning that keeps students actively engaged and leads to deeper understanding of the material. And it works. Youth Build students have the best attendance records and highest rates of graduation at Little Metro. Students appear to enjoy the work, and they are highly incentivized to succeed, both financially and in terms of future job prospects. Meanwhile, they are also expected to complete their academic capstones, so participation in the program does not preclude education in more traditional areas.

Youth Build is the crown jewel in Little Metro's trade programs, but there are other opportunities and a willingness on the part of the administration to try new programs, depending on student interest and need. A relatively new teacher is building a program in horticulture and landscaping, which includes training in beekeeping (the school has a hive on the roof). She and her crew do landscaping for the homes that the Youth Build crews have built. Ultimately, she'd like to build a full blown urban agriculture program, with opportunities to learn about city gardening and animal husbandry, and environmental care in an urban context. Healthcare is another area of interest for many students. All students get trained in first aid and CPR, as a requirement for graduation. This has led some students to seek certification in phlebotomy or take beginning courses in EMT training or nursing. Over the years, Little Metro has offered courses in forklift certification or beginning welding. Each year, the school makes an effort to survey students and respond to their areas of interest as best they can. The overarching goal of the trade programs is to help students explore possible careers, while also moving in practical ways toward postsecondary opportunities.

\section{Pushback: Ongoing Challenges and Potential Pitfalls at Little Metro}

Above, we have focused on the qualities that we believe allow Little Metro to succeed with students, but this is not to say that everything is perfect. As at any school, challenges and problems also arise. In this next section, we push back on some of Little Metro's practices and highlight some of the potential pitfalls.

Extreme Flexibility: Some who visit Little Metro might ask: Is there too much flexibility? Does the school's extreme flexibility sometimes enable problematic habits that undermine success? Is academic rigor possible in a setting where absenteeism and apathy about school are common? Both staff and students expressed some concern about this issue. One teacher described his hesitancy in this way:

James: Sometimes I feel like the way we help our kids is both good and bad. I hope I'm not babying them too much because not every teacher or boss in their future will be like that. (Hmong American male math teacher)

Other staff members wondered if there may be a need for "tough love" from time to time, particularly when students are failing to meet basic expectations for attendance and progress. 


\section{LCNAEDULATION \\ 27-29 March, 2020 \\ Oxford, United Kingdom}

It's important to point out that rigor does exist at Little Metro. There are opportunities for students to earn college credit. Students participate in robotics competitions and solar-powered boat contests. During our visits, we witnessed moments of higher level learning in various subjects and we saw evidence of project-based work that required effort and deep understanding. At the same time, we also met many students who just didn't seem to think of themselves as academically oriented. This meant that they needed teachers who were patient with them and good at helping them build confidence and self-esteem. In other words, they needed teachers who were flexible.

Rather than framing extreme flexibility as a weakness, we would describe it as a conscious choice with both negative and positive consequences. Extreme flexibility at Little Metro makes rigor more sporadic and may at times reinforce negative habits, such as poor attendance and a hesitancy to tackle academic challenges. Meanwhile, such flexibility makes it possible for Little Metro to reach the students it seeks to serve, students who have not succeeded in more structured environments and clearly need something different. It is precisely because the school privileges relationships and community ahead of academic achievement that many of its students find pathways toward success. The ongoing difficulty for teachers is striking the right balance between providing that individualized support, while also pushing students to challenge themselves and do their best.

Staying Small vs Scaling Up: As noted, the current leadership is committed to staying small, because they see the school's size as central to its mission and success. Meanwhile, that very success has led to increasing pressures to grow. Currently, Little Metro does not advertise or market its program beyond a simple webpage and word of mouth, but they always have a wait list. Leadership hates the idea of turning away students in need, but they also see staying small as a necessary part of their success. The director has also been encouraged at various times to "scale up" by recreating similar programs elsewhere (as many successful charters attempt to do). "We would love to see our successes reproduced in other settings," she admits, "and there are some charters and contract schools out there with similar approaches. But our focus needs be on our kids here and that means staying small." While it is true that some alternative schools in the area use similar approaches, there are still many students in the large, traditional schools who are at risk of dropping out or falling through the cracks. One purpose of this study is to "get the word out" about what is working at Little Metro and elsewhere, in the hopes that more alternative programs may take root. We also hope the traditional system might consider adopting some alternative approaches for struggling students.

Race: The dynamic of race is complex at most schools in the U.S., and Little Metro is no exception. Though it has a higher percentage of teachers of color (approximately 15\%) than statewide averages (4-5\%), white teachers still make up the majority of staff in a school made up mostly of students of color. This can put additional pressures on staff of color, and it may affect the ability of white teachers to connect with students and build those relationships of trust. In a city, state, and country where race relations are strained, there are bound to be race-related challenges at school. Based on our observations and conversations, we believe that Little Metro is aware of these challenges and doing everything it can to address them. Several recent hires have been Hmong-American teachers, which aligns with student demographics. Many teachers at Little Metro are highly committed to anti-racist frameworks as a central part of their pedagogy. 


\section{LENAEDUCATION

Continuity of Leadership: Highly effective leadership makes a qualitative difference at any school and replacing that leadership during times of transition is difficult. Though Mary shows no signs of slowing down, everyone at Little Metro knows that the school is highly dependent on her leadership - her commitment to the mission, her institutional knowledge and connections in the community, and her seemingly boundless energy for students. Replacing her (which may necessary within five years) will be a challenge. One teacher admits, "This school is really Mary's baby. I'm not sure what we're going to do when she leaves. No one is ever going to replace her, but maybe there's some sort of shared leadership that can happen." Based on the quality of the teaching staff and their commitment to the mission, we believe that the school will find a way to weather this challenge, but there is no question that Mary's retirement will require the school to adapt and evolve.

\section{Conclusion}

In conclusion, we propose and define our own framework of pedagogical and institutional plasticity, an approach to schooling which we see as crucial to success when working with adolescents who have faced adverse childhood experiences (ACEs) and are at risk of dropping out or experiencing the school-to-prison pipeline.

Schools which practice pedagogical and institutional plasticity are willing and able to adapt and change in response to student need. Classrooms tend to be highly student-centered spaces, with flexible curricula, project-based learning, and differentiated instructional approaches. Culturally responsive and culturally sustaining pedagogies promote critical awareness and link learning to real world problems (Ladson-Billings, 1995; Gonzalez \& Amanti, 2005; Paris \& Alim, 2017). Student-centeredness also extends to advising and guidance, where students receive the individual attention they need, first to establish trust and build a relationship, then to ensure that students have the resources they need to meet their needs and develop a personal education plan that initiates a trajectory of success.

At the institutional level, a philosophy of plasticity eschews rigid discipline policies (such as zero tolerance) and leans heavily toward restorative justice practices, where student voice is valued and consequences focus on repairing injustice, re-establishing healthy relationships, and building a strong community (Davis, 2013; Smith 2015). Through peer-mediation or adultsupervised conversations, students participate in seeking to understand what went wrong and how it can be repaired; consequences are individualized and context-specific (Dalporto, 2013; Smith, 2015). Institutional plasticity also refers to school-wide programming, which ideally provides motivational hooks that garner student interest and encourage re-engagement with school. School leaders plan explicitly for multiple points of entry throughout the year and creative responses to chronic absenteeism. As with classroom instruction, programming is malleable and highly responsive to student needs and interests. School leaders are open to trying new programmatic ideas as they arise.

The purpose of this paper, as well as others in the series, has been to highlight one alternative program that is successfully practicing pedagogical and institutional plasticity. We hope that it can serve as a model for those seeking to educate students who have not succeeded in 
the traditional system. It is imperative that we not give up on the students at the heart of this study. Little Metro fulfills this vital mission through highly personalized and relational teaching, one student at a time. As one student shared with us: "This school saved my life."

\section{References}

Alexander, M. (2012). The new Jim Crow: Mass incarceration in the age of colorblindness. New York, NY: New Press.

Basford, L., Lewis, J. (2018). A reason to be angry: A mother, her sons, and the school-to-prison pipeline (2nd Edition). In Nocella, A., Parmar P. \& Stovall, D. (Eds.) From Education to Incarceration: Dismantling the School to Prison Pipeline. Peter Lang Publishing.

Lewis, J. \& Basford, L., (2014). Paying with their lives: One family and the school-to-prison pipeline. In Ngo, B \& Kumashira, K. (eds). Six lenses for anti-oppressive education: Partial stories, improbable conversations. New York: Peter Lang.

Crenshaw, K., Ocen, P., \& Nanda, J (2015). Black girls matter: Pushed out, overpoliced, and underprotected. African American Policy Forum. Center for Intersectionality and Social Policy Studies.

Blitz, L.V., Anderson, E.M., \& Saastamoinen, M. (2016). Assessing perspectives of culture and trauma in an elementary school: Informing a model for culturally responsive trauma informed schools. Urban Review, 48, 520-542. Doi: 10.1007/s11256-016-0366-9

Bornstein, D. (2013, Nov 13). Schools that separate the child from the trauma. New York Times, 2-5.

Christle, C., Jolivette, K., \& Nelson, C. (2005). Breaking the school to prison pipeline: Identifying school risk and protective factors for youth delinquency. Exceptionality, 13(2), 69-88.

Davis, M. (2013). Restorative justice: Resources for schools. Edutopia. Retrieved from https://www.edutopia.org/blog/restorative-justice-resources-matt-davis

Dalporto, D. (2013). Restorative justice: A different approach to discipline. We are teachers. Retrieved from http://www.weareteachers.com/restorative-justice-a-different-approach-to-discipline/

Freeman, J. (2014). Dropout prevention. The sage encyclopedia of classroom management. 
Thousand Oaks, CA: Sage. Doi: 10.4135/9781483346243.n111

Ganzel, B., \& Morris, P. (2011). Allostasis and the developing human brain: Explicit consideration of implicit models. Development and Psychopathology, 23, 955-974.

Gonzalez, N., Moll, L. \& Amanti, C. (2005). Funds of knowledge: Theorizing practice in households, communities and classrooms. Mahwah, NJ: Lawrence Erlbaum Associates.

Heitzeg, N. (2009). Education or incarceration: Zero tolerance policies and the school to prison pipeline. Forum on Public Policy Online, 2009(2).

Iachini, A., Buettner, C., Anderson-Butcher, D., \& Reno, R. (2013). Exploring Students' Perceptions of Academic Eengagement in a Dropout Recovery Setting. Children \& Schools, $35(2)$.

Ladson-Billings, G. (1995). But that's just good teaching! The case for culturally relevant pedagogy. Theory into Practice, 34(3), 159-165.

Merriam, S (1998). Qualitative research and case study applications in education. San Francisco, CA: Jossey-Bass.

Minnesota Department of Health (2011). Adverse childhood experiences in Minnesota. Executive Summary.

Morgan, A., Pendergast, D., Brown, R., \& Heck, D. (2015). Relational ways of being an educator: t trauma-informed practice supporting disenfranchised young people. International Journal of Inclusive Education, 19(10), 1037-1051, Doi: 10.1080/13603116.2015.1035344 T

Morris, M (2018). Pushout: The criminalization of black girls in schools. New York, NY: New Press.

Nocello, A., Parmar, P., \& Stovall, D. (2014). From education to incarceration: Dismantling the school-to-prison pipeline. New York, NY: Peter Lang Publishing.

Noguera, P. (2008). What discipline is for: Connecting students to the benefits of learning. In M. Pollock (Ed.), Everyday antiracism: Getting real about race in schools (pp. 132-138). New York, NY: New Press.

Paris, D. \& Alim, H.S. (2017). Culturally sustaining pedagogies: Teaching and learning for justice in a changing world. New York, NY: Teachers College Press. 
Sciaraffa, M., Zeanah, P., \& Zeanah, C. (2017). Understanding and promoting resilience in the context of adverse childhood experiences. Early Childhood Education Journal, 46:343-353. Doi:10.1007/s10643-017-0869-3.

Smith, D. (2015). Better Than carrots or sticks: Restorative practices for positive classroom management. Alexandria, Virginia: Association for Supervision and Curriculum Development.

Stevens, B. (2013). Evening the odds in American justice. Moyers and Company. Interview with Bill Moyers, March 29, 2013.

Stevens, J. (2018). ACES too high. https://acestoohigh.com/

Stopa, J. E., Barrett, P. M., \& Golingi, F. (2010). The prevention of childhood anxiety in socioeconomically disadvantaged communities: A universal school-based trial. Advances in School Mental Health Promotion, 3(4), 5-24. Doi: 10.1080/1754730X.2010.9715688

Woods-Jaeger, B., Cho, B., Sexton, C., Slagel, L., \& Goggin, K (2018). Promoting resilience:

Breaking the intergenerational cycle of adverse childhood experiences. Health Education \& Behavior 1-9. 